In order to facilitate the pheasant research programme in east-central Illinois, a mobile nightlighting rig was designed. The night-lighting apparatus was also found to be useful for observing and studying the behaviour of animals during the hours of night. This study technique is particularly valuable when many animals have been marked for individual recognition.

\section{Stone-fruit Viruses}

IN serological and physical studies of stone-fruit viruses, R. S. Willison, M. Weintraub and J. H. Tremaine have reported that strain $Y .4$ of the cherry yellows virus was purified from cucumber by four methods (Canadian J. Bot., 37, No. 6, 1157 ; 1959). These differed mainly at the clarification stage. Two of the methods, which are given in detail, yielded infective preparations. The virus was usually inactivated by freezing. Ultra-violet absorption spectrum analysis, and particle-size and sedimentationrate determinations, supported by infectivity tests, indicated that, in these infective preparations, the virus replaced most if not all of the components found in comparable extracts from healthy sources. The agar-gel diffusion technique was used for precipitin tests. Virus antigen from cucumber sources reacted with homologous antiserum or with antiserum derived from infected cherry petals and vice versa.

\section{Letters written by Frédéric or Irène Joliot-Curie}

P. BIquard, writing on behalf of the Association Frédéric et Irène Joliot-Curie, Institut du Radium, 11 rue Pierre-Curie, Paris 5e, asks if readers of Nature possessing letters written by Frédéric or Irène JoliotCurie would inform him. It is one of the aims of this Association to publish such correspondence, and it would like to receive such letters, or photocopies. The letters will only be published if their owners give the necessary authorization.

\section{Classical Languages in Oxford Entrance Require- ments}

Congregation at Oxford has approved a scheme proposed by the Committee for Admission to the University for new entrance requirements. The position of Latin and Greek was the topic of widest interest in the new proposals, under which Latin would no longer be essential. The Committee for Admission recommended exemption from Latin for those who have a pass at Advanced Level in a General Certificate of Education examination or a college award in mathematics or science. This proposal was accepted, and a statute embodying the decision will be brought before Congregation next term. To become effective, the statute will require a two-thirds majority.

\section{Colombo Plan Appointments}

In a written answer in the House of Commons on February 12, the Minister of State for Commonwealth Relations, Mr. R. Thompson, stated that in consultation with the Government of India, the United Kingdom Government is arranging to recruit and provide, under the Technical Co-operation Scheme of the Colombo Plan, ten members of the professorial staff of the College of Engineering and Technology in the University of New Delhi, and two science workshop supervisors. It is intended that the professorial appointments should be for average periods of five years.

\section{Announcements}

Sir Harry Menville, secretary of the Department of Scientific and Industrial Research, will formally open the new laboratories of the Coil Spring Federation Research Organization in Sheffield on March 24 (see Nature, 184, 777 ; 1959).

THE twenty-fourth meeting of the European Federation of Chemical Engineering will take the form of an International Symposium on Distillation, which will be held in Brighton during May 4-6. Further information can be obtained from the Institution of Chemical Engineers, 16 Belgrave Square, London, S.W.1.

UNDER the auspices of the Laboratory Animals Centre, a symposium on the Provision of Animals for Cancer Research will be held at the Royal Society of Medicine on May 23. Further information can be obtained from the Secretary, Laboratory Animals Centre, Medical Research Council Labolatories, Woodmansterne Road, Carshalton, Surrey.

THE Department of Mechanical, Civil and Chemical Engineering, Royal College of Science and Technology, Glasgow, is organizing a symposium on Nuclear Reactor Containment Buildings and Pressure Vessels during May 17-20. Further information can be obtained from the Secretary of the Royal College of Science and Technology, Glasgow, C.1.

The Royal Microscopical Society is arranging a two-day meeting in conjunction with the Electron Microscopy Group of the Institute of Physics, to be held in Leeds on March 31 and April 1, to discuss "Co-ordination of Light and Electron Microscopy". Application forms can be obtained from the Secretary, Royal Microscopical Society, Tavistock House South, Tavistock Square, London, W.C.1.

THE seventh international congress of the European Ceramic Association is to be held in London during May 23-28. The purpose of the conference is to establish opportunities for the discussion of common interests and problems between specialists from all parts of western Europe. Further information can be obtained from the organizing secretary, Mr. H. O. Cox, 36 Victoria Street, London, S.W.1.

The Chemical Society, the Institute of Petroleum, the Royal Institute of Chemistry and the Society of Chemical Industry are jointly organizing a symposium to be held in the Chemistry Lecture Theatre, the University of Manchester, on March 24, on the Industrial Chemistry of the Lower Olefines. Further information can be obtained from Dr. P. J. King, Department of Chemical Engineering, Manchester College of Science and Technology, Sackville Street, Manchester 1.

Dr. Marie Boas's book "Robert Boyle and Seven. teenth Century Chemistry" (Cambridge University Press, 30s. net; see Nature, 183, 850 ; 1959) has been awarded the Pfizer Prize of the History of Science Society for the best book on the history of science by an American author published in 1958. "The Rotation of the Earth", by Prof. W. Munk and Dr. G. J. F. MacDonald of the University of California, has been awarded the Monograph Prize of 1959 of the American Academy of Arts and Sciences for a work on a physical or biological subject. This book, a Cambridge Monograph on Mechanics and Applied Mathematics, will be published by the Cambridge University Press this autumn. 